\title{
AS ESTATUETAS DE TERRACOTAEAS PRÁTICAS RELIGIOSAS PRIVADAS NO EGITO GRECO-ROMANO
}

\author{
Marcia Severina Vasques*
}

\begin{abstract}
VASQUES, M.S. As estatuetas de terracota e as práticas religiosas privadas no Egito grecoromano. Rev. do Museu de Arqueologia e Etnologia, São Paulo, 14: 103-116, 2004.
\end{abstract}

RESUMO: As estatuetas de terracota constituem uma documentação material importante para o estudo da religião no Egito greco-romano. Feitas em série, por meio de moldes, elas eram destinadas, sobretudo, ao culto doméstico e às práticas religiosas privadas. Abordaremos neste artigo algumas representações de Ísis e de Harpócrates, que estão diretamente relacionadas à questão da fertilidade, seja ela humana ou agrária. Temos por objetivo mostrar que estas representações, apesar de se expressarem exteriormente em formas artísticas gregas, estão respaldadas na tradição religiosa nativa, sendo um foco de resistência da cultura egípcia tradicional, funcionando como figuras propiciatórias de abundância e prosperidade tanto neste mundo quanto no Além.

UNITERMOS: Egito greco-romano - Terracotas - Religião popular.

\section{Introdução}

Estatuetas de terracota foram produzidas em grande quantidade no Egito greco-romano. Sua confecção em série, por meio de moldes, reduzia o seu custo e as tornava acessíveis a uma ampla camada da população. A terracota já era utilizada no Egito faraônico, inclusive na confecção de estatuetas. No entanto, a preferência por este material no período greco-romano se deveu à influência grega e à sua técnica de manufatura por meio de moldes, prática que se tornou comum para a produção de terracotas no mundo grego a partir do século VI a.C. As terracotas circulavam por todo o território egípcio e mesclavam elementos das tradições egípcia nativa e clássica. Sendo usadas como ex-votos depositados nos templos,

(*) Museu de Arqueologia e Etnologia da Universidade de São Paulo. Doutoranda, Bolsista-CNPq. marcia-vasques@uol.com.br como oferendas funerárias ou como objetos de culto doméstico, as terracotas tiveram um amplo papel na religiosidade popular do Egito greco-romano.

Utilizamos aqui o termo Egito greco-romano por estarmos lidando com um material, a estatueta de terracota, que sofreu poucas mudanças estilísticas durante o período em que foi utilizado. A longa vida da maior parte dos tipos é determinada por conceitos religiosos e iconográficos que permaneceram inalterados durante séculos. Na verdade, $\mathrm{o}$ Egito ptolomaico (305-30 a.C.) e o romano (30 a.C. -395 d.C.) devem ser considerados separadamente, pois ambos os períodos históricos possuem especificidades próprias e não devem ser enquadrados numa análise única. ${ }^{1}$ No entanto, preferimos esta denominação porque, embora a maioria dos tipos aqui tratados seja dos séculos II e III d.C., a origem de muitos motivos iconográficos remonta ao período ptolomaico .

(1) Para a discussão do problema, ver Montserrat (1996: 15). 
VASQUES, M.S. As estatuetas de terracota e as práticas religiosas privadas no Egito greco-romano. Rev. do Museu de Arqueologia e Etnologia, São Paulo, 14: 103-116, 2004.

Muitas destas terracotas trazem motivos iconográfícos relacionados à questão da fertilidade, seja ela humana ou agrária. Propomos discutir esta presença de elementos associados à fertilidade em alguns exemplares de terracota, com destaque para as representações de Ísis e de Harpócrates. Não pretendemos, com isso, esgotar o assunto, que, por si só, já é muito extenso e complexo. Mas tentaremos esboçar uma opinião a respeito.

À guisa de introdução sobre as terracotas egípcias do período greco-romano, discutiremos, inicialmente, a distinção tradicional entre terracotas produzidas em Alexandria e as da chor ${ }^{2}$ em seguida, abordaremos a questão da religião privada e, depois, analisaremos alguns exemplares destas terracotas.

\section{Alexandria e a chora}

A maior parte das terracotas hoje presentes nas coleções de museus são fruto de escavações arqueológicas antigas, que datam sobretudo do final do século XIX e início do XX. Estava ausente destas pesquisas uma preocupação mais sistemática com vários aspectos que envolvem uma pesquisa arqueológica, principalmente aqueles que dizem respeito ao contexto arqueológico. Assim, muitas peças chegaram aos museus sem dados de procedência, dificultando tanto a sua datação quanto a definição exata do lugar de sua proveniência, aspecto que engloba do contexto específico de achado (tumbas, ambientes domésticos, santuários etc.) às regiões do Egito onde foram encontradas (Fayum, Baixo Egito, Médio Egito etc.).

Devido à carência de informações, o critério de distinção das terracotas foi baseado na qualidade de sua confecção e nos repertórios iconográficos utilizados. As terracotas produzidas no Egito foram comumente divididas, pelos especialistas, entre as alexandrinas e as da chora. Os modelos mais helenizados, de melhor qualidade e de repertório iconográfico grego eram atribuídos a uma confecção de Alexandria e datados do período ptolomaico, enquanto aqueles produzidos com uma argila menos adequada e com um padrão egípcio mais

(2) O Egito inteiro era considerado como sendo a chora (incluindo as metrópoles), em oposição a Alexandria, a pólis por excelência (Rowlandson 1998: xvii). acentuado eram considerados como pertencentes à chora e de época romana.

Este modelo de interpretação é preconceituoso na sua proposição, já que considera que as estatuetas mais "belas" e de melhor feitura provêm de Alexandria e estão mais próximas do padrão estético clássico. E as mais "egípcias" são consideradas de qualidade inferior. Atualmente, este conceito tem sido revisto. Ballet (1995: 259) afirma ser necessária uma releitura das figurinhas de terracota greco-egípcias, pois as estatuetas produzidas na chora poderiam ser de excelente execução. Alem disso, tanto os motivos iconográficos egípcios poderiam estar presentes em Alexandria quanto os gregos, na chora. Segundo Ballet (1995: 262), as imagens do tipo grego estavam bem implantadas na província e não eram tipos exclusivos do meio alexandrino. A distinção entre os tipos iconográficos poderia ser feita mais no plano cronológico do que geográfico (Ballet 1995: 243). $\mathrm{Na}$ verdade, muitos tipos iconográficos transitavam por todo o Egito. Ainda que os motivos clássicos fossem mais comuns na Alexandria do período ptolomaico, em época romana não há como distinguir por este critério os centros de produção.

As primeiras terracotas produzidas em Alexandria trazem assuntos profanos. São representações de mulheres em pé, com véu, ou sentadas, adolescentes, portadoras de guirlandas, musicistas etc. São os tipos classificados como semelhantes aos de Tanagra e Mirina. ${ }^{3}$ Análises de argilas de exemplares encontrados nas necrópoles orientais de Alexandria feitas por Clifford (apud Ballet 1995: 218) revelaram que era utilizada a argila da região do Delta, fato que indica a existência de uma produção local. Temas puramente

(3) Tanagra, da Beócia, na Grécia, foi importante centro de produção de terracotas, de aproximadamente 320 a.C. a 200 a.C. Os coroplatas (fabricantes de figurinhas) de Tanagra aplicavam os modelos das estatuetas de bronze na sua produção de terracota. Os motivos principais eram temas da vida cotidiana com uma grande representação de figuras femininas. Parece que os fabricantes de terracotas de Tanagra migraram para Mirina, cidade da Ásia Menor, no século III a.C. As primeiras representações de Mirina, encontradas nas tumbas, seguem os modelos de Tanagra. Elas adquirem um estilo próprio a partir do século II a.C. Os temas predominantes também são aqueles relativos à vida cotidiana, sendo comuns representações de personagens ligados ao ciclo de Afrodite e Dioniso. 
VASQUES, M.S. As estatuetas de terracota e as práticas religiosas privadas no Egito greco-romano. Rev. do Museu de Arqueologia e Etnologia, São Paulo, 14: 103-116, 2004.

egípcios também estavam presentes em Alexandria. Destacam-se as representações de Harpócrates, freqüentes nas necrópoles orientais e nos chamados Montes Testacei ${ }^{4}$

Já as terracotas consideradas como produção da chora eram comumente chamadas de "provinciais", "greco-egípcias" ou de "terracotas do Fayum". Sua característica principal é a argila aluvial, de cor castanha escura, contendo muita mica e algumas partículas vegetais. No entanto, Török (1995: 18) acredita não ser possível determinar as oficinas de fabricação por meio da cor da argila, sendo esta uma descrição subjetiva. Para ele, a identificação das oficinas só é possível quando sabemos a proveniência do material. Como as terracotas eram feitas no molde, torna-se difícil estabelecer o local de origem das mesmas, pois os modelos circulavam entre as oficinas do país. A homogeneidade iconográfica das terracotas egípcias deve-se à alta padronização da iconografia e à conotação religiosa das estatuetas, duas razões para os mesmos motivos serem comuns a todo o Egito

A qualidade modesta das terracotas da chora deve-se à sua produção abundante, derivada à sua fabricação em série e não ao seu local de fabricação. A cidade de Mênfis, por exemplo, possuía oficinas com ótimo padrão de produção (Ballet 1998: 243). Métodos mais modernos de averiguação têm sido aplicados à análise do material cerâmico, mas, por enquanto, o resultado de sua análise química não permite uma definição exata do lugar de produção destas estatuetas. Estas terracotas podem ser datadas do século I a.C. ao IV d.C.. No entanto, pode-se considerar que o maior volume de sua produção situa-se nos séculos II e III d.C.

\section{As práticas religiosas privadas}

As estatuetas de terracota exerciam um importante papel nas práticas religiosas privadas do Egito greco-romano. A religião "privada" ou "popular" era aquela praticada diariamente pelas pessoas comuns e se contrapõe, neste sentido, à religião oficial dos templos, a cargo dos sacerdotes.

(4) Este termo compreende, segundo Ballet (1998: 220), as tumbas helenísticas tardias e romanas das necrópoles orientais e também os depósitos próximos a elas associados.
Atualmente, considera-se mais adequado o uso do termo "práticas religiosas privadas" ou "religião privada" ao invés de "religião popular" (Dunand 1991: 292). Isto porque o termo "religião popular" foi cunhado, inicialmente, para distinguir a religião ofícial dos templos daquela da prática popular, freqüentemente associada à magia e à superstição. Sabemos que esta distinção conceitual é falsa, pois deriva da visão cristã dos cultos da Antigüidade Tardia. A religião egípcia sempre esteve intrinsecamente imbuída de concepções mágicas. Neste sentido, não há distinção entre elementos mágicos sendo operados nos objetos de culto popular, como as terracotas, e as grandes imagens dos templos, por exemplo.

Práticas religiosas privadas seriam aquelas realizadas na esfera doméstica, sem a intermediação direta de um sacerdote ou oficiante de culto. Entre estas práticas religiosas privadas se destaca a chamada religião de piedade, voltada para as necessidades mais urgentes da população, ocasião na qual os devotos pediam às divindades graças relativas aos problemas cotidianos da vida comum: saúde, fertilidade, boas colheitas, proteção às mães e às crianças etc. Takács (1995: 8) define piedade como um relacionamento recíproco e individual entre o devoto e a divindade, que se manifesta por meio de um culto.

Aspectos destas práticas religiosas privadas podem ser visualizados nas estatuetas de terracota, nas quais a maior parte das figurações dizem respeito às preocupações cotidianas dos habitantes do Egito greco-romano: por exemplo, doenças, complicações de parto e cuidado com as crianças, entre outras. No entanto, as terracotas não eram somente objetos de culto doméstico. Eram também depositadas em templos como ex-votos e em tumbas, fazendo parte do mobiliário funerário.

Frankfurter (1998: 73) afirma que o culto mortuário, no período romano, acabou se tornando um assunto da religião doméstica. Isto porque com o esfacelamento do sistema tradicional egípcio, a mumificação e os aparatos funerários deixaram de ser feitos pelos colégios de sacerdotes e passaram para as mãos de guildas mortuárias. Assim, a grande tradição egípcia do deus Osíris e o complexo sistema mitológico da vida após a morte foram englobados pela religião local, na esfera doméstica. Em muitas partes do Egito o culto mortuário tornou-se, em grande parte, responsabilidade da família. 
VASQUES, M.S. As estatuetas de terracota e as práticas religiosas privadas no Egito greco-romano. Rev. do Museu de Arqueologia e Etnologia, São Paulo, 14: 103-116, 2004.

\section{Ísis}

No período faraônico Ísis possuía um importante papel como esposa-irmã de Osíris. Deusa poderosa nas artes mágicas, Ísis fez a primeira múmia do corpo de Osíris e protegeu seu filho, Hórus, das artimanhas de Seth, assassino de Osíris e usurpador do trono real. A representação tradicional de Ísis era a de uma divindade com o sinal hieroglífico, que significa trono, sobre a cabeça, o que a revela como uma divindade associada ao poder real, sendo a própria personificação do trono. Como mãe do faraó, Hórus encarnado, Ísis tinha também um importante papel maternal e era comum a sua representação sentada no trono amamentando Hórus criança, motivo freqüente nas estatuetas de bronze que datam do Período Tardio (713-332 a.C.).

No período greco-romano Ísis aparece associada a diversas divindades femininas, egípcias mesmo ou gregas. Esta assimilação de divindades não era estranha à cultura egípcia. Segundo Hans Bonnet (1999: 183), o sincretismo era um elemento crucial e constitutivo da religião egípcia. Quando um deus em especial alçava à categoria de divindade nacional, os deuses locais não eram descartados e sim, de alguma forma, sobrepostos à divindade principal, sem com isso perder suas características próprias (Bonnet, op. cit.: 185-186). Esta visão é compartilhada por Hornung (1992: 83), segundo o qual o sincretismo egípcio permite a combinação de divindades de diversas maneiras. Observamos este processo na figura de Ísis que, no período imperial romano, incorpora praticamente todas as divindades femininas, sejam elas egípcias ou estrangeiras.

Já no período faraônico Ísis havia se apropriado de diversos atributos de Háthor, como o disco solar entre os chifres de vaca e o sistro. ${ }^{5}$ Háthor, cujo nome significa "morada de Hórus", era originalmente uma deusa celeste, pois o céu era a morada do falcão, Hórus. Possuidora de inúmeros aspectos, Háthor era deusa do amor, do prazer, da alegria, da música e da dança, sendo a personificação do princípio feminino por excelência. No seu

(5) Instrumento musical que consistia em um arco, podendo ser de metal ou de outro material, como a faiança, atravessado por três varas horizontais, que continham pequenos pratos também de metal, os quais emitiam som quando chacoalhados. aspecto funerário assumia a forma de Deusa do Ocidente, Amentet, que se estende ao flanco da montanha e deixa o sol e os mortos penetrarem nas regiões inferiores. Como filha de Rê é o "Olho do Sol" adquirindo o aspecto de uma leoa, a deusa Sekhmet. Quando apaziguada, tomava a forma de uma gata, a deusa Bastet, protetora do lar e da família. Como deusa da sexualidade Háthor foi associada a Afrodite no período greco-romano. E, por intermédio de Háthor, adveio a assimilação entre Ísis e Afrodite.

Uma outra forma composta de Ísis, comum no período greco-romano, era com a deusa egípcia Renenutet, que era representada com cabeça de mulher e corpo de serpente. Deusa da colheita e dos grãos, Renenutet estava ligada à fertilidade agrária. Seu nome significa "a cobra que nutre". Desempenhava um papel funerário de proteção aos mortos e também era uma deusa que presidia aos nascimentos. Em grego, era chamada Ermuthis ou Thermuthis. Ao que parece, a associação de Ísis com Deméter se deu via Renenutet. No entanto, Ísis já aparece associada a Deméter em Heródoto (II, 64-65). Ísis-Thermuthis era representada segurando tochas e espigas de trigo.

Na maior parte das representações de Ísis, nas terracotas, a deusa foi retratada segundo os cânones da arte grega: usando uma túnica longa e um manto com franjas, que era atado, entre os seios, com um nó. Seu penteado podia ser à maneira egípcia, como uma peruca ou em estilo grego, em mechas caindo sobre os ombros ou divididos em gomos (côtes de melon), ${ }^{6}$ segundo a moda romana do período. Seu atributo característico era a coroa composta pelo disco solar entre os chifres de uma vaca, duas plumas e, em cada lateral da coroa, uma espiga de trigo, ${ }^{7}$ podendo aparecer também outros acessórios como a pele de abutre ${ }^{8} \mathrm{e}$ o uraeus. ${ }^{9}$ Nas mãos, ela podia levar um sistro,

(6) Penteado comum nos séculos II e III d.C.

(7) $\mathrm{O}$ disco solar entre os chifres de vaca era um atributo de Háthor, divindade egípcia com a qual Ísis se identifica. Esta coroa hathórica, acrescida pelas espigas e plumas, recebia o nome de basileîon, a típica coroa de Ísis no período greco-romano.

(8) O abutre, ave associada ao princípio feminino, significava "mãe" e era símbolo da deusa Mut, identificada com a mãe do faraó e também com a rainha, que usava um toucado formado com o corpo desta ave. Era símbolo também do Alto Egito na figura da deusa Nekhbet. 
VASQUES, M.S. As estatuetas de terracota e as práticas religiosas privadas no Egito greco-romano. Rev. do Museu de Arqueologia e Etnologia, São Paulo, 14: 103-116, 2004.

uma sítula, ${ }^{10}$ uma espiga de trigo, ${ }^{11}$ uma tocha ${ }^{12}$ ou um uraeus, dependendo do tipo iconográfico. Em muitos destes aspectos Ísis está associada às deusas gregas Deméter e Afrodite, mas também a outras divindades egípcias como Háthor, Bastet e Renenutet.

Muitas representações de Ísis e de mulheres associadas ao seu culto estão intrinsecamente vinculadas às questões relativas à fertilidade, tanto agrária como humana. Alguns estudiosos, como Françoise Dunand (1979: 107-108), apontam que as representações de Ísis em estatuetas de terracota serviam às preocupações mundanas e terrenas das pessoas mais simples, que trabalhavam no campo e que estavam preocupadas com problemas cotidianos relacionados à saúde, maternidade, proteção às crianças etc. Neste sentido, seu papel funerário tradicional, como mãe e esposa de Osíris, estaria relegado a um segundo plano. Para Dunand (1979: 107-108), somente as representações de ÍsisThermuthis teriam conservado a função funerária de Ísis. Concordamos que, à primeira vista, esta proposição esteja correta. No entanto, devemos atentar que as representações de Ísis, em seus variados aspectos, estavam integradas em um ciclo de representações, que englobava vários aspectos da religião egípcia tradicional e que possuía um propósito mais amplo, não apenas relacionado à questão agrária e à fertilidade, mas também às preocupações relativas à vida após a morte. Estes aspectos também estão presentes em vários outros tipos de terracotas produzidos no Egito neste período. Retomaremos com mais detalhe esta questão após fazermos um apanhado dos tipos isíacos e da representação de Harpócrates nas terracotas.

(9) A palavra grega "uraeus" parece ter se originado da expressão egípcia "aquela que se ergue", que se refere à cobra naja. A serpente era o emblema do Baixo Egito, na figura da deusa Uadjet, da cidade de Buto. Associada ao sol, ela era a protetora do faraó, sendo colocada sobre o diadema real.

(10) Pequeno vaso cuja forma assemelha-se a um seio. Era usado para conter oferenda de água ou leite.

(11) Atributo das divindades associadas à fertilidade agrária, como Ísis e Deméter.

(12) A tocha estava presente, para gregos e romanos, nas principais ocasiões da vida, nos períodos que encerram os chamados "ritos de passagem", ou seja, por ocasião do nascimento, do casamento e da morte. A tocha na mão de Ísis tem, provavelmente, um significado ctônio e a identifica, neste aspecto, com Deméter.
Isis, quando representada em pé, geralmente, segura em uma das mãos um sistro e, na outra, uma sítula. Tanto o sistro, instrumento musical associado à deusa Háthor, quanto a sítula, vaso em forma de seio usado para colocar a água do Nilo ou leite, eram atributos de fertilidade. A serpente uraeus, às vezes levada na mão da deusa, desempenhava uma função agrária, estando associada à fertilidade do solo (Fig. 1). As espigas também se relacionam com este tema. A função maternal de Ísis é mais explícita ainda nas representações de Isis-Lactans, nas quais a deusa está amamentando seu filho, Harpócrates ou Ápis (Fig. 2).

$\mathrm{O}$ aspecto da fertilidade também está presente nas figurações de Ísis quando relacionada a outras divindades, sejam egípcias, como Renenutet ou gregas, como Deméter e Afrodite. Nas representações de Ísis-Thermuthis a deusa é figurada metade mulher e metade serpente e tem por atributos a tocha e espigas de trigo (Fig.3). A fertilidade agrária estava intrinsecamente relacionada ao aspecto funerário, de renascimento e vida após a morte.

Já nas representações de Ísis-Afrodite a deusa é representada nua e traz, sobre a cabeça, um calathos,${ }^{13}$ que pode levar em relevo a coroa isíaca. Neste tipo de representação é difícil discernir a figura da deusa daquelas de mulheres relacionadas ao seu culto. Três tipos de representações se destacam: em primeiro lugar, a de mulheres nuas com os braços colados ao corpo (Fig.4); em seguida, a de mulheres que erguem a túnica, a fim de mostrar o sexo, neste caso são chamadas de anasirmena (Fig.5) e estão associadas aos cultos de Bastet e Háthor e, por fim, a representação de Ísis-Afrodite anadiômena (Fig.6), a que mais se aproxima da Afrodite grega ${ }^{14}$.

A primeira representação, de mulheres nuas com os braços colados ao corpo, lembra as representações das chamadas "concubinas do morto". "Estas eram figurinhas de terracota que, no período faraônico, eram depositadas nas tumbas e

(13) Cesto usado para colocar flores, frutos, espigas e produtos da colheita. Era associado às divindades da fertilidade como Dioniso, Afrodite e Deméter. (14) É aquela que acabou de surgir da espuma do mar e está torcendo os cabelos.

(15) Assim chamadas porque se pensava, erroneamente, que eram figuras de mulheres destinadas a servir sexualmente o morto no Além. Também foram encontradas em tumbas femininas. 


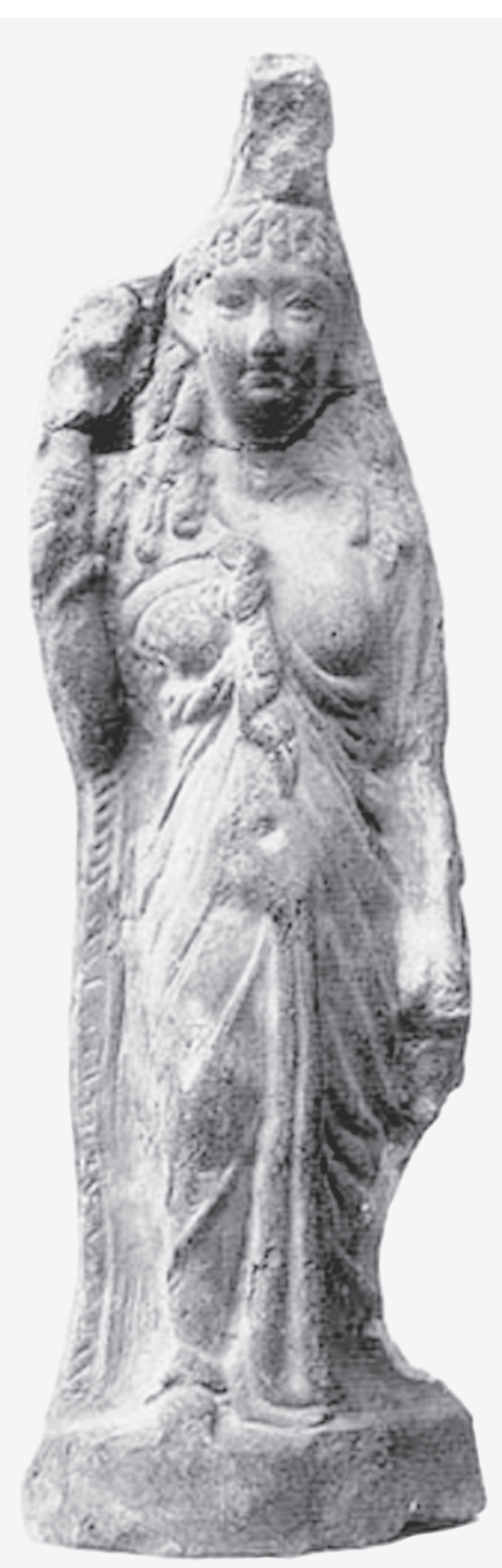

Fig. 1 - Ísis em pé (Dunand 1990: 148-149, fig. 396).

tinham a função de propiciar ao morto, de ambos os sexos, um renascimento para uma nova vida.

Provavelmente, estavam associadas à deusa Háthor.

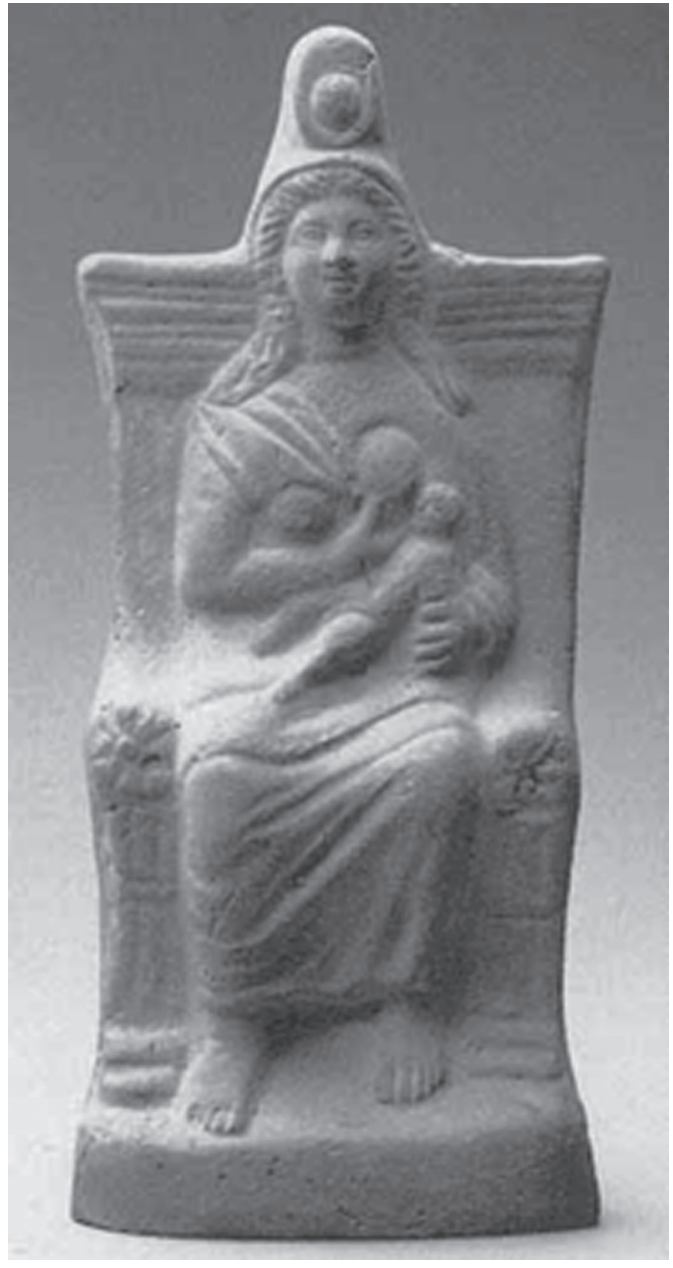

Fig. 2 - Isis-Lactans (Ewigleben; Grumbkow 1991: 55, fig. 33).

Outro exemplo, do Egito faraônico, para esta representação de mulheres nuas como símbolo de renascimento para uma outra vida, está nas pinturas de algumas tumbas privadas do Novo Império. São representações de jovens nuas, que servem os convivas em cenas de banquete. Segundo Brancaglion (1999: 161), o aspecto sexual destas cenas tinha por função assegurar a fertilidade do morto e, assim, fazer com que ele renascesse para a nova vida. As representações de mulheres erguendo a túnica e mostrando o sexo também possuem várias referências no Egito faraônico. Nas festividades consagradas a Bastet ou Bubástis, na cidade do mesmo nome, as mulheres erguiam as vestes buscando adquirir fertilidade (Heródoto, II, 60). Este 
VASQUES, M.S. As estatuetas de terracota e as práticas religiosas privadas no Egito greco-romano. Rev. do Museu de Arqueologia e Etnologia, São Paulo, 14: 103-116, 2004.

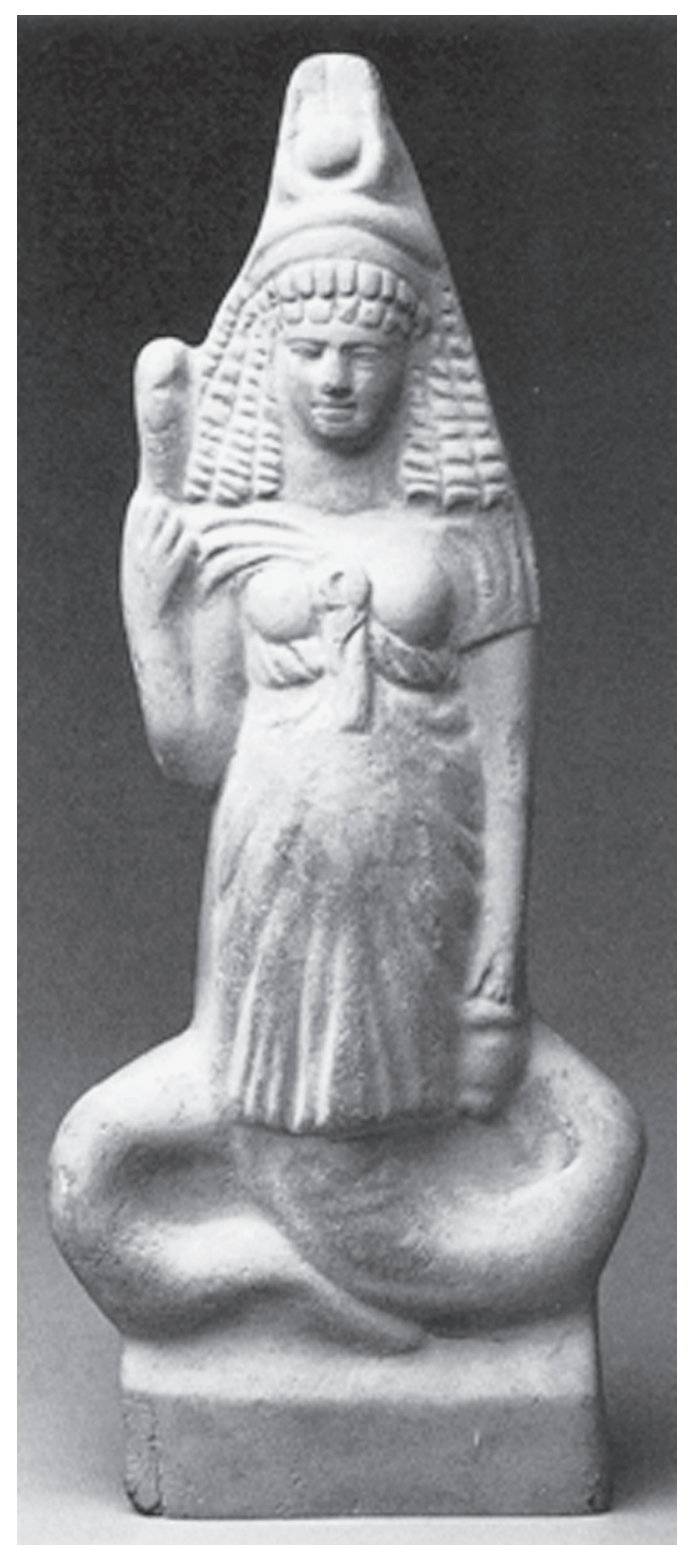

Fig. 3 -Ísis-Thermuthis (Ewigleben; Grumbkow 1991: 58, fig. 39).

procedimento também era comum quando do aparecimento do novo Ápis, touro sagrado de Mênfis. Antes de ser apresentado oficialmente à população, o recém-nascido recebia a visitação das mulheres, que erguiam as vestes diante dele em um ritual de fertilidade (Diodoro, I, 85, 3). Segundo Montserrat (1996: 168-69), a exposição do novo Ápis às mulheres, quando este estava ainda vulnerá-

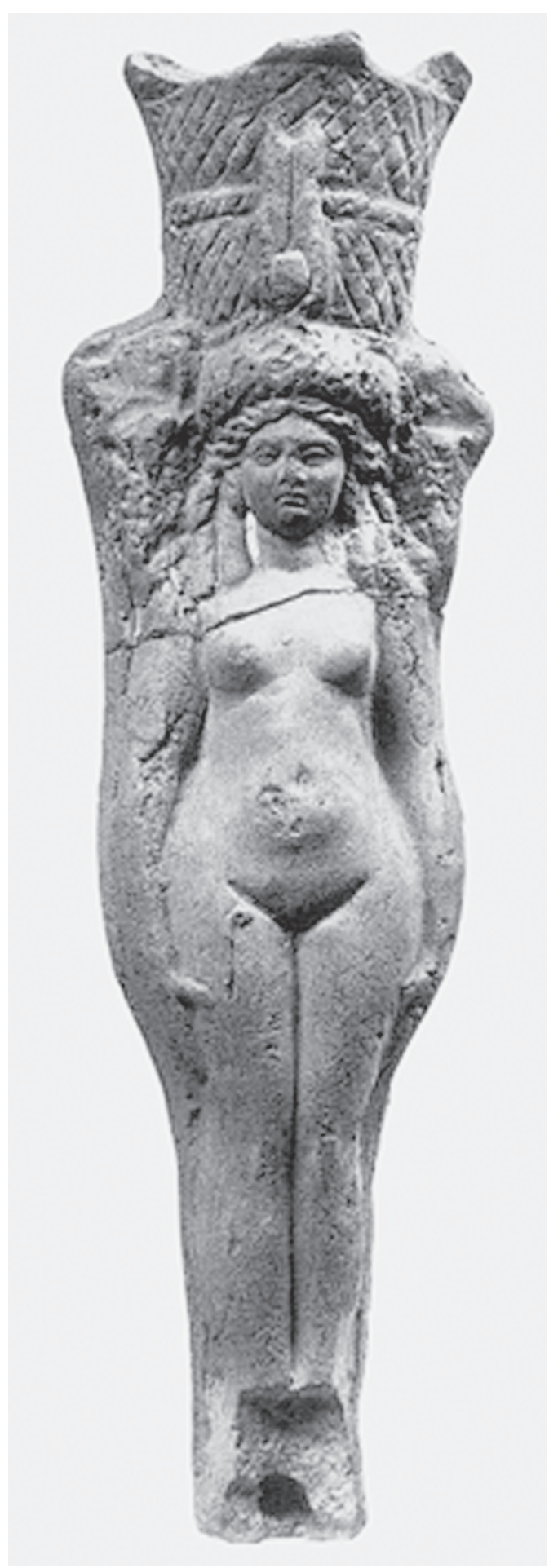

Fig. 4 -Ísis-Afrodite (Dunand 1990: 130-131, fig. 339). 
VASQUES, M.S. As estatuetas de terracota e as práticas religiosas privadas no Egito greco-romano. Rev. do Museu de Arqueologia e Etnologia, São Paulo, 14: 103-116, 2004.

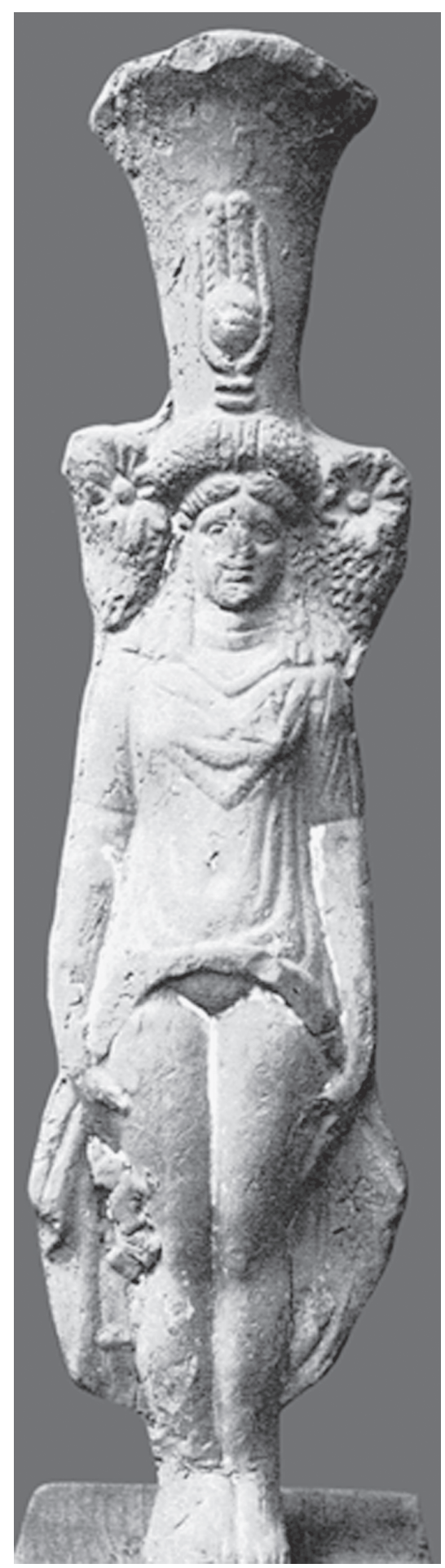

Fig. 5 - Ísis-Afrodite anasirmena (Dunand 1979: 186-187, pr. XXXVII, fig. 60) .

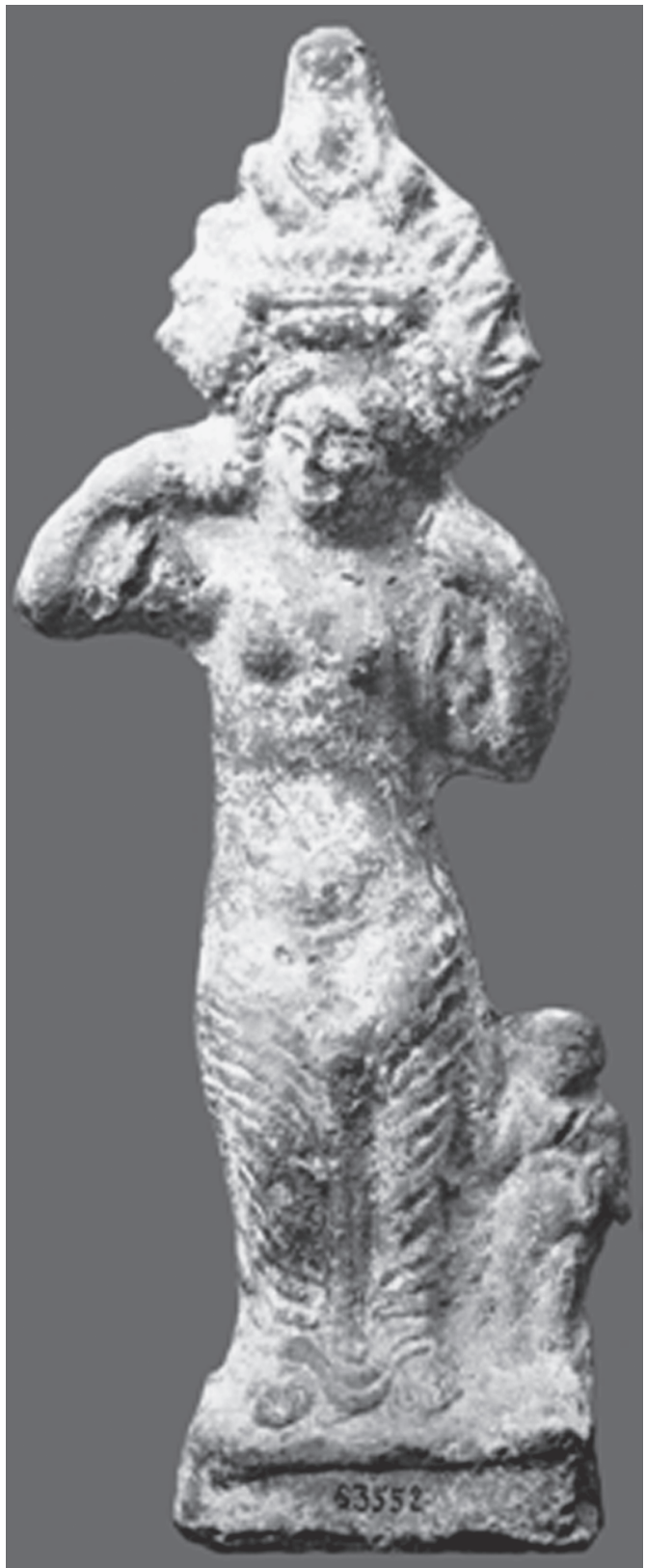

Fig. 6 - Ísis-Afrodite anadiômena (Dunand 1979: 186 pr. XXXVI, fig. 59).

vel pela sua pouca idade, poderia ter uma função apotropaica. O mesmo sentido teria o gesto da deusa Háthor diante de seu pai Rê, nos episódios da "Contenda entre Hórus e Seth". Rê estava zangado e de mau humor. Para restaurar sua boa vontade, Háthor lhe mostra seus genitais. 
VASQUES, M.S. As estatuetas de terracota e as práticas religiosas privadas no Egito greco-romano. Rev. do Museu de Arqueologia e Etnologia, São Paulo, 14: 103-116, 2004.

Vimos que em uma grande parte das representações de Ísis, seja sozinha ou associada a outras divindades, como Ísis-Thermuthis ou Ísis-Afrodite, a deusa porta atributos relacionados à fertilidade, seja agrária ou feminina. Várias figuras femininas associadas a Ísis também apresentam um caráter protetor, apotropaico e têm uma ação mágica como propiciadoras de abundância e prosperidade. E, quando depositadas em tumbas, tinham a função de reforçar os aspectos sexuais de regeneração e renascimento, uma alusão à perpetuação da vida no outro mundo.

\section{Harpócrates}

Outra figura importante nas estatuetas de terracota é a de Harpócrates, denominação de Hórus criança. Filho de Ísis e Osíris, vingou a morte de seu pai e ocupou o trono do Egito, que havia sido usurpado por seu tio, Seth. Os gregos lhe atribuíam também o nome de Carpócrates, de karpos (grão, semente), pela sua associação com os ritos agrários. Harpócrates era retratado no repertório iconográfico das terracotas como uma criança com o dedo na boca, usando a mecha lateral da infância e portando, sobre a cabeça, $\mathrm{o}$ pschent ${ }^{16} \mathrm{O}$ culto de Harpócrates teve um grande destaque no período greco-romano. Segundo Törok (1995: 20), pode ter sido o papel desempenhado por Harpócrates na realeza, fazendo parte da tríade com Serápis e Ísis, que promoveu o desenvolvimento de seu culto doméstico.

Como protetor das crianças e da família, Harpócrates era uma divindade doméstica. Uma representação comum do deus no repertório iconográfico das terracotas o mostra nu, com um grande falo, portando sobre a cabeça o pschent $\mathrm{e}$ segurando um pote, ao qual, às vezes, leva a mão como que para pegar algum alimento (Fig.7). Acredita-se que este pote continha um prato tipicamente egípcio, especialmente reservado às crianças, feito com farinha e lentilhas. Parece que o mesmo pote ovóide era levado nas mãos pelos sacerdotes de Harpócrates (Malaise, 1994: 374). Esta representação provavelmente estava associada ao festival devotado a Harpócrates, relacionado à comida, a Harpocrateia, na qual, segundo Frankfurter (1998: 54), provavelmente, eram distribuídos doces para as crianças. Além deste vaso oval, Harpócrates também era representado segurando uma cornucópia ${ }^{17}$ (Fig.8). Ambos são símbolos da abundância e da prosperidade.

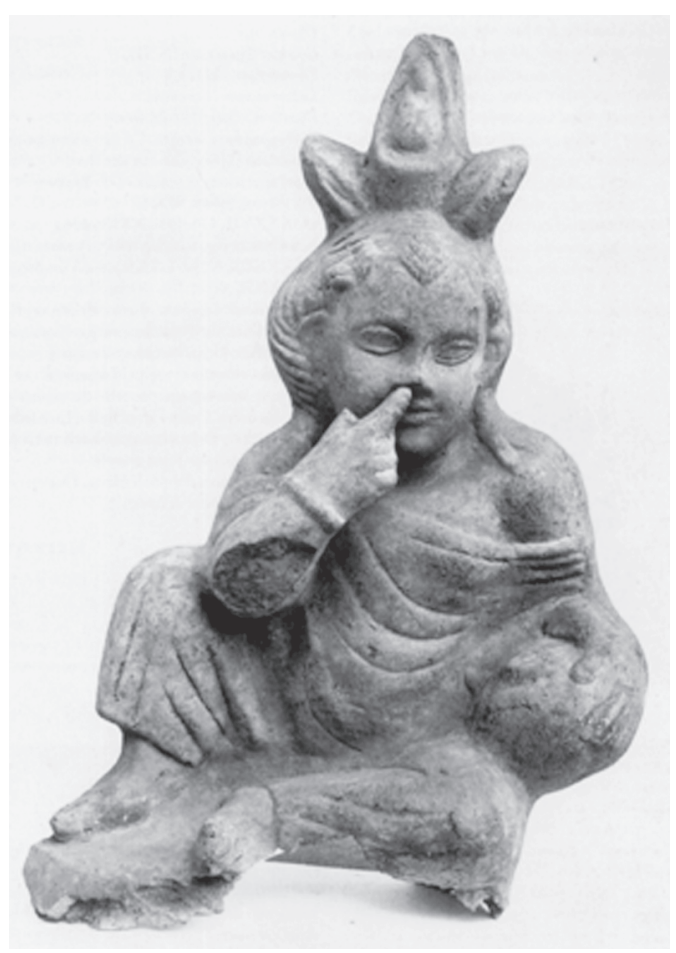

Fig. 7 - Harpócrates com pote (Dunand 1990: 69, fig. 126).

A representação de Harpócrates podia variar conforme a divindade a que estava associado. Muitas vezes era tratado também como um deus itifálico, associado a Min, Bés e a Príapo, todas divindades que exerciam algum papel relacionado à atividade sexual. O primeiro, Min, era um deus itifálico da fertilidade e da potência sexual masculina. No período greco-romano foi associado a Pã, sendo a sua cidade, Akhmin, chamada pelos gregos de Panópolis. Sua representação tradicional era a de um homem mumificado, portando sobre a cabeça uma coroa com duas plumas, segurando seu 
VASQUES, M.S. As estatuetas de terracota e as práticas religiosas privadas no Egito greco-romano. Rev. do Museu de Arqueologia e Etnologia, São Paulo, 14: 103-116, 2004.

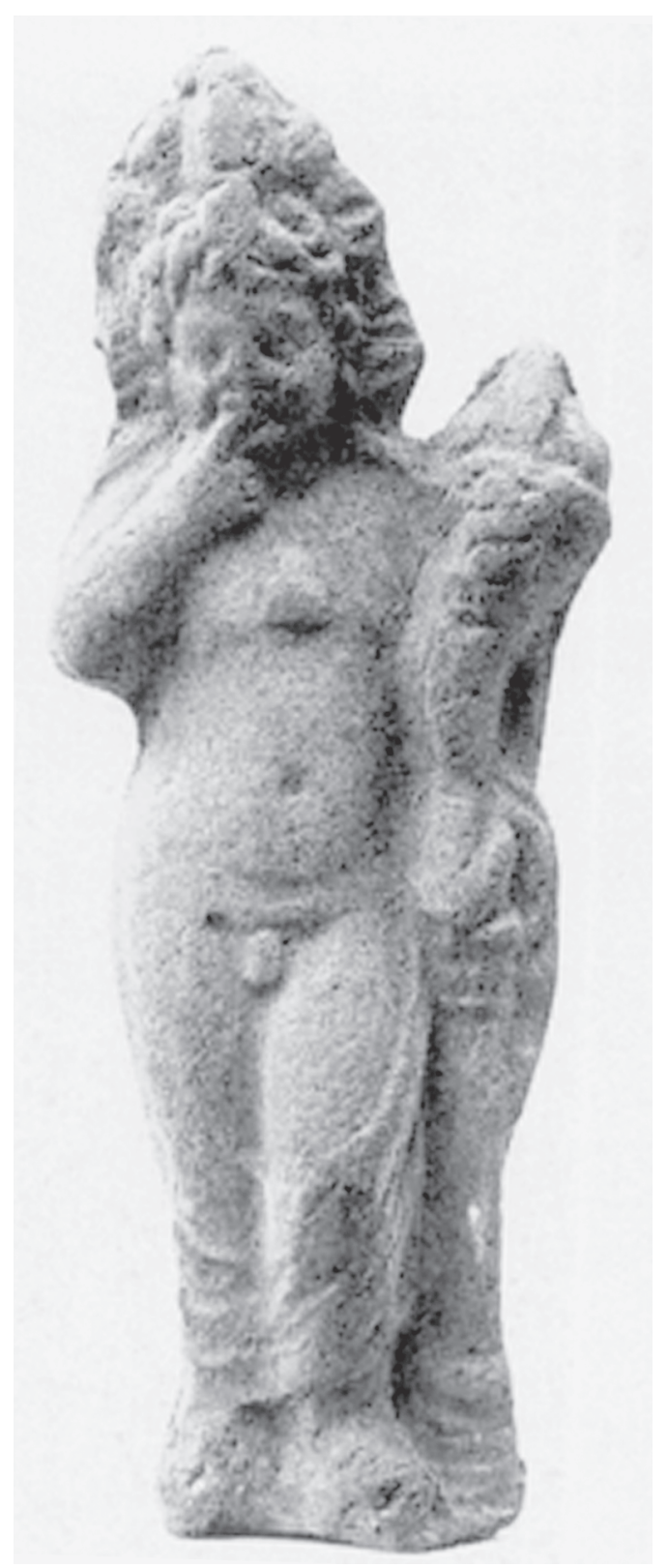

Fig. 8 - Harpócrates com cornucópia (Dunand 1990: 78, fig. 155).

falo ereto com a mão esquerda e tendo a mão direita erguida segurando um açoite. Às vezes, Min era assimilado a Hórus, sendo chamado de filho de Ísis. Já Bés era um deus benéfico, protetor da casa, da família e das crianças. Deus-anão com características faciais grotescas e com uma língua protuberante,
Bés era retratado freqüentemente com orelhas e juba de leão, usando um toucado de plumas e carregando instrumentos musicais ou facas. Existia um santuário de Bés, em Saqqara, datando do período ptolomaico, com vários cômodos decorados com pinturas e relevos retratando Bés e mulheres nuas. As figuras eróticas serviam magicamente para se adquirir a fertilidade, se destacando o componente erótico da concepção (Frankfurter 1998: 127). Príapo também era um deus da potência divina, deus da fertilidade agrária e da fecundidade do rebanho, guardião dos campos e dos jardins. Era uma figura importante nos Mistérios Orientais, principalmente órficos e dionisíacos, pois sua força geradora era importante para assegurar aos fiéis a imortalidade.

As representações de Harpócrates com um grande falo, seguindo o tipo do grotesco fálico, se relacionam, segundo Törok (1995: 20) ao culto de Ptah-Sokar-Osíris. Sokar era um antigo deus falcão da cidade de Mênfís. Era uma divindade ctônia que foi, na sua origem, um deus dos artesãos. Com o desenvolvimento do culto de Osíris, Sokar foi a ele assimilado, assim como a Ptah, divindade principal de Mênfis. Esta união das três divindades data, provavelmente, do Médio Império. Devido à sua associação com a religião funerária, o papel de Harpócrates, não se reduz, para Törok (1995: 21), à religião de cunho privado. Harpócrates era o protetor das crianças mas também desempenhava um importante papel como uma divindade funerária, cuja função mágica visava garantir ao morto uma vida eterna.

Harpócrates era um deus associado à vida, à fertilidade e à criação. Aparece relacionado a mitos cosmogônicos, como o da criança que nasce da flor de lótus, ou a deuses criadores, como Khnum, Ptah e Âmon. Como a criança que nasce do lótus primordial, Harpócrates era identificado ao deus Nefertum, simbolizando o surgimento do sol e a origem da vida (Fig.9). Segundo um dos mitos da cosmogonia egípcia, das águas primordiais, o Nun, emergiu uma flor de lótus, da qual nasceu um deus na forma de uma criança, simbolizando o sol, Rê. Segundo Sauneron (1992: 68), esta seria uma tradição que teve origem na cidade de Hermópolis. Posteriormente, o lótus foi identificado com o deus Nefertum, adorado em Mênfis. No "Livro dos Mortos" (cap. 81) havia um encantamento para transformar o morto em Nefertum porque ele era "o lótus no nariz do deus sol" (Hart 1990: 16). 
VASQUES, M.S. As estatuetas de terracota e as práticas religiosas privadas no Egito greco-romano. Rev. do Museu de Arqueologia e Etnologia, São Paulo, 14: 103-116, 2004.

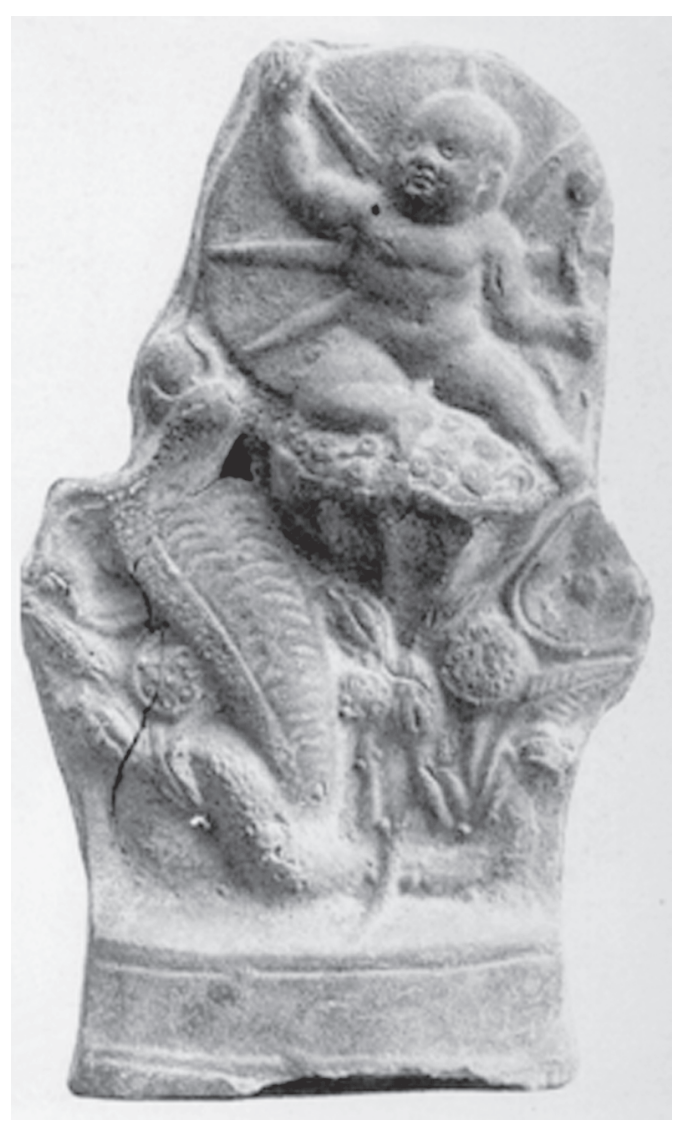

Fig. 9 - Harpócrates surgindo de uma flor de lótus (Dunand 1990: 95, fig. 210).

Vários animais, importantes quanto às questões relativas à potência sexual ou à fertilidade, aparecem representados com Harpócrates. Em geral, estes animais, como o ganso (Fig.10) e o carneiro (Fig. 11), poderiam estar relacionados tanto com divindades egípcias quanto gregas. No Egito, o carneiro aparece ligado às divindades associadas a algum mito cosmogônico. É o caso, por exemplo, de Âmon, de Ptah e de Khnum. Este último era um deus criador, da Ilha de Elefantina, representado com cabeça de carneiro. Deus oleiro, havia modelado em seu torno as formas da criação, os seres vivos, os vegetais e também as formas geográficas do mundo. Também estava associado com a cheia do Nilo, sendo o guardião das fontes deste rio. Já Âmon era um deus tebano, que formava a tríade familiar com Mut e Khonsu. Poderia ser representado com cabeça de carneiro. Seu nome significa "o oculto", porque sua identida-

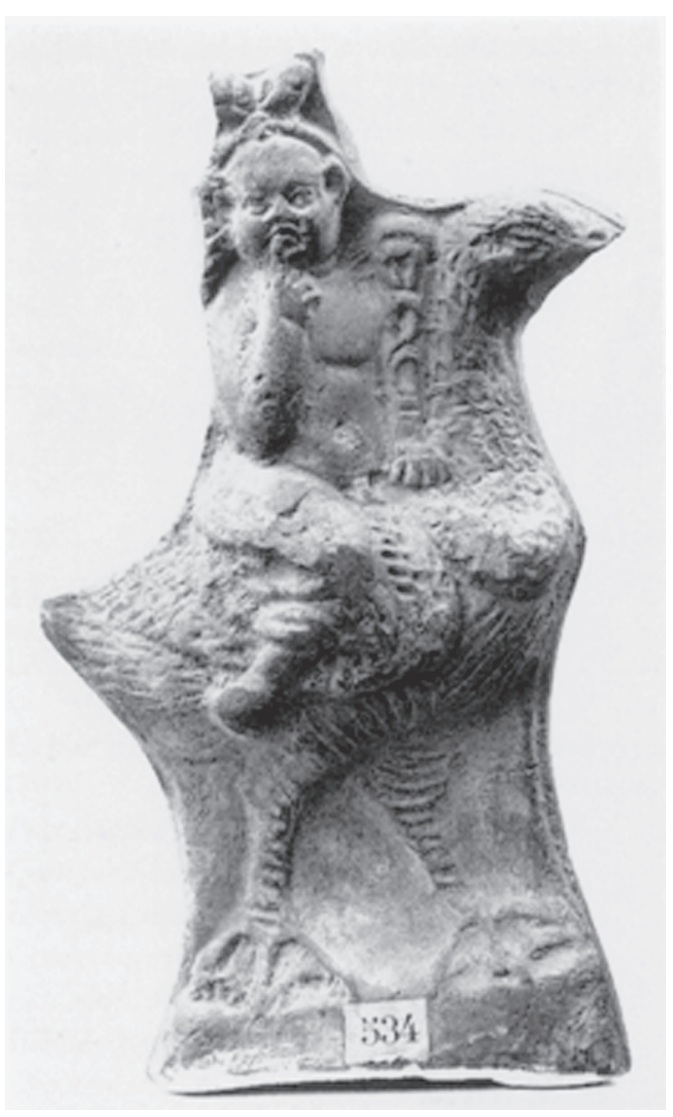

Fig. 10 - Harpócrates montado sobre um ganso (Dunand 1990: 89-90, fig. 191).

de misteriosa nunca poderia ser revelada. Como deus itifálico é associado a Min e descrito como Âmon Kamutef (literalmente "o touro de sua mãe"). Ptah era o deus criador de Mênfis, sendo geralmente retratado como uma múmia segurando um cajado, que combina o pilar djed, ${ }^{18}$ o sinal $a n k h^{19} \mathrm{e}$ o cetro was. ${ }^{20}$ No período ptolomaico, Ptah foi identificado a Hefaísto, por ser o deus dos artesãos.

Um outro deus carneiro era Heryshef, que os gregos chamavam de Arsaphes. Deus solar associado à fertilidade, Heryshef foi identificado

(18) Símbolo da estabilidade, representava a espinha dorsal de Osíris.

(19) Ou cruz ansata, símbolo da vida, que figura nas mãos das divindades benfeitoras.

(20) Cetro carregado pelos deuses, que termina em forma de forquilha e tem a cabeça de um animal, provavelmente um canídeo. Símbolo da potência divina. 


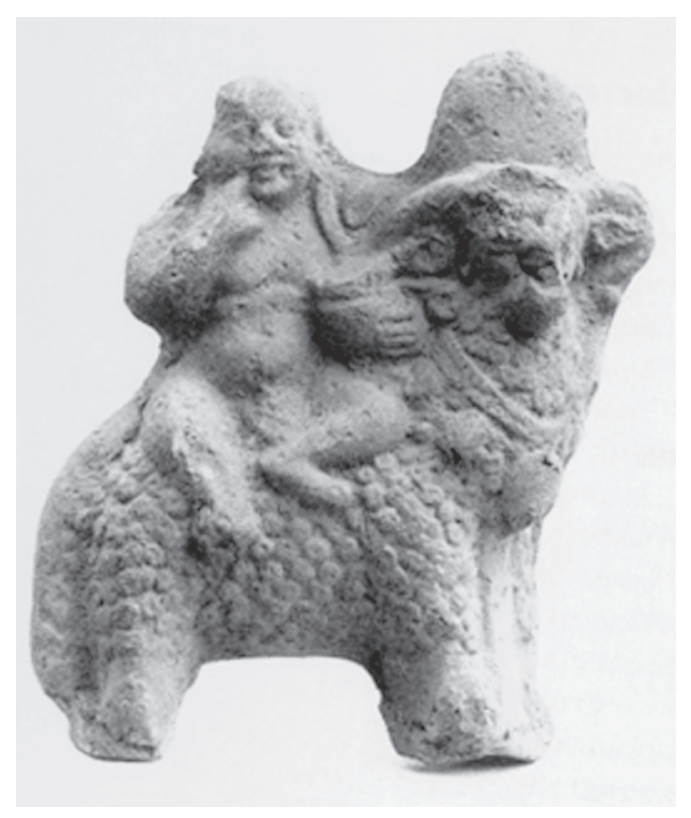

Fig. 11 - Harpócrates montado sobre um carneiro (Dunand 1990: 92, fig. 198).

pelos gregos a Héracles. Deus demiurgo, seu nome significa "aquele que está sobre seu lago", uma referência às águas do oceano primordial. Várias divindades ovinas existiam no Egito e muitas delas eram consideradas como sendo o $b a$ de Rê ou de Osíris, porque o som onomatopaico da palavra egípcia para carneiro era semelhante à palavra o $b a$, que designa a "alma" do morto, seu espírito móvel. É o caso, por exemplo, do carneiro da cidade de Mendes, considerado a manifestação do $b a$ de Osíris.

Todas estas características de Harpócrates reforçam que ele era uma divindade associada à vida, um deus solar criador, que vencia a luta contra o caos e a morte, instaurando a vitória da ordem e da vida. Emúltima instância, sua função era manter Maat.

\section{Considerações finais}

Concluindo, podemos notar que a maior parte dos atributos destas terracotas são símbolos de fertilidade e estão associados ao aspecto sexual. Tanto as várias representações de Ísis com os seus atributos de fertilidade, quanto as divindades a ela identificadas, estão relacionadas a ritos de fecundidade, que englobam os aspectos da maternidade e o ato de propiciar uma boa colheita agrícola. Asexualidade presente nas figuras de Harpócrates também se relaciona a este aspecto da prosperidade e fecundidade, que remonta à religião egípcia tradicional.

$\mathrm{O}$ ato sexual estava vinculado, no Egito, à idéia de regeneração, de vida e, portanto, era considerado essencial no prolongamento da vida após a morte. Os atributos característicos das divindades, sejam relacionados à fertilidade agrária - como o uraeus, o calathos, a cornucópia e a espiga de trigo - ou à humana - como as representações de Isis-Lactans e de mulheres nuas - se inserem em um ambiente religioso totalmente respaldado na religião egípcia tradicional, que sobrevive utilizando-se de formas artísticas derivadas da tradição greco-romana.

Para Frankfurter (1998), à medida que os templos egípcios perderam o poder e terminaram por se enfraquecer no final do período imperial romano, os cultos e as crenças tradicionais foram mantidos pela religião privada. As terracotas passaram a desempenhar um importante papel no culto doméstico e também funerário. Ísis e Harpócrates são duas divindades que se destacaram no período ptolomaico e romano. E ambas incorporaram elementos de outras divindades egípcias, que poderiam estar assimiladas a elas em um determinado contexto. Uma das divindades que está relacionada diretamente a Ísis e Harpócrates é Osíris, embora a representação deste não seja tão freqüente entre as terracotas. Sabemos que a prática da mumificação era extensa no período greco-romano e que os cultos funerários continuaram até a conversão total do Egito ao cristianismo. Osíris era um deus agrário, sua morte e ressurreição representavam o ciclo da cheia e do decréscimo das águas do Nilo. Deus associado à fertilidade, também poderia ser representado itifálico. Este caráter fértil de Osíris está diretamente ligado a ele como uma divindade ctônia, do mundo dos mortos, capaz de propiciar uma nova vida no Além.

Por meio destes aspectos de fertilidade o ciclo de representações se fecha: nascimento-morterenascimento. Portanto, os aspectos das crenças relativas à morte e ao além-túmulo não estão excluídos desta produção de terracotas. São conceitos religiosos egípcios tradicionais que se mantiveram no sistema de crenças relativo à piedade popular, no contexto do culto local e doméstico. Este fato demonstra a resistência da cultura local adaptada às novas circunstâncias trazidas pelo contato com gregos e, posteriormente, romanos. 
VASQUES, M.S. As estatuetas de terracota e as práticas religiosas privadas no Egito greco-romano. Rev. do Museu de Arqueologia e Etnologia, São Paulo, 14: 103-116, 2004.

VASQUES, M.S. The terracotta statuettes and religious private practices in Graeco-Roman Egypt. Rev. do Museu de Arqueologia e Etnologia, São Paulo, 14: 103-116, 2004.

ABSTRACT: The terracotta statuettes constitute an important material documentation for the study of the religion in Graeco-Roman Egypt. Produced in series, through molds, they were intended, above all, to domestic cult and private religious practices. We will deal in this article with some representations of Isis and of Harpocrates, that are directly related to the subject of the fertility, either human or agrarian. Our aim is to show that these representations, their outward expression in Greek artistic forms nothwithstanding, are supported by native religious tradition, being a focus of resistance of the traditional Egyptian culture, and working as propitiatory illustrations of abundance and prosperity as much in this world as in the Beyond.

UNITERMS: Graeco-Roman Egypt - Terracottas - Private religion.

\section{Referências bibliográficas}

ABDEL-AZIZ, H.

1995 Ithyphallic Harpocrates in Graeco-Egyptian magic. In: Congresso Internazionale ItaloEgiziano. Alessandria e il mondo ellenisticoromano: Alessandria, 23-27 novembre, 1992. Roma, L'Erma di Bretscheneider: 9-11.

\section{ASSMANN, J.}

1989 Maât: L'Égypte pharaonique et l'idée de justice sociale. Paris: Julliard.

BALLET, P.

1995 Terres cuites gréco-égyptiennes du Musée d'Alexandrie. In: Congresso Internazionale Italo-Egiziano. Alessandria e il mondo ellenistico-romano: Alessandria, 23-27 novembre, 1992. Roma, L'Erma di Bretscheneider: 259-264.

1998 Terres cuités d'Alexandrie et de la chôra Essai d'étude comparative de quelques ateliers. Thèmes et e techniques. $\mathrm{BCH}$, Athènes, supp. 33: 217-243.

\section{BONNET, $\mathrm{H}$.}

1999 On Understanding Syncretism. Orientalia, Roma, 68(3): 181-214.

BRANCAGLION JR., A.

1999 O banquete funerário no Egito Antigo Tebas e Saqqara: tumbas privadas do Novo Império (1570-1293 a.C.). Tese (Doutorado em Antropologia). São Paulo, Faculdade de Filosofia, Letras e Ciências Humanas, Universidade de São Paulo.

BUDGE, E.A.W

1993 O Livro Egípcio dos Mortos. Tradução Octavio Mendes Cajado. São Paulo: Ed. Pensamento.

\section{CUMONT, F}

s/d Priapus. In: E. Saglio (Dir.) Dictionnaire des Antiquités Grecques et romaines. Paris: Librairie Hachette. Tome 4, $1^{\text {a }}$ partie: 645-647. DIODORODA SICÍLIA

1993 Bibliothèque Historique. Livro I. Paris: Les Belles Lettres. Versão francesa de Yvonne Vernière, do original grego.

DUNAND, F.

1979 Religion Populaire en Égypte Romaine. Les terres cuites isiaques du Musée du Caire. Leiden: E. J. Brill.

1990 Catalogue des terres cuites gréco-romaines d'Égypte. Paris: Éditions de la Reunion des Musées Nationaux.

DUNAND, F. ; ZIVIE-COCHE, CH.

1991 Dieux et Hommes en Égypte 3000 av. J.-C.395 apr. J.-C. Paris: Armand Colin.

ÉGYPTE ROMAINE. L'AUTRE ÉGYPTE.

1997 Musées de Marseille. Réunion des Musées Nationaux.

EMPEREUR, J.Y. (Ed.)

1998 Commerce et artisanat dans l'Alexandrie Hellénistique et Romaine. Actes du Colloque d'Athènes (11-12 décembre 1998).

EWIGLEBEN, C.; GRUMBKOW, J.

1991 Götter, Gräber \& Grotesken: tonfiguren aus dem Alltagsleben em römischen Ägypten.

FISCHER, J. Hamburg: Museum für Kunst und Gewerbe.

1995 The change of religious subjects in GraecoRoman coroplastic art. In: Congresso Internazionale Italo-Egiziano. Alessandria e il mondo ellenistico-romano: Alessandria, 23- 
VASQUES, M.S. As estatuetas de terracota e as práticas religiosas privadas no Egito greco-romano. Rev. do Museu de Arqueologia e Etnologia, São Paulo, 14: 103-116, 2004.

27 novembre, 1992. Roma, L'Erma di Bretscheneider: 308-313.

FRANCO, I.

1993 Petit Dictionnaire de Mythologie Égyptienne. Paris: Éditions Entente.

\section{FRANKFURTER, D.}

1998 Religion in Roman Egypt. Assimilation and Resistance. Princeton/New Jersey: Princeton University Press

HART, G.

1990 Egyptian Myths. London: British Museum Press.

\section{HERÓDOTO.}

1982 Histoires. Livro II. Paris: Les Belles Lettres. Versão francesa de E. Legrand, do original grego. HORNUNGE

1992 Les Dieux de l'Égypte. L'Un et le multiple. Tradução Paul Couturiau. [S.L.]: Flamarion.

LURKER, M.

1982 The Gods and Symbols of Ancient Egypt. New York: Thames and Hudson.

MALAISE, $\mathrm{M}$

1994 Questions d'iconographie harpocratique soulevées par des terres cuites d'Égypte gréco-romaine. Hommages à Jean Leclant. III - Études Isiaques. Institut Français d'Archéologie Orientale: 373-383.

MONTSERRAT, D.

1996 Sex and Society in Graeco-Roman Egypt. London and New York: Kegan Paul International.

PASQUALI, M.I.

1995 Su alcune tipologie di Arpocrate nelle terrecotte figurate. In: Congresso Internazionale Italo-Egiziano. Alessandria e il mondo ellenistico-romano: Alessandria, 23.
27 novembre, 1992. Roma: L'Erma di Bretscheneider, 1995: 393-397.

PENSABENE, $P$.

1995 Il tempio di tradizione faraônica e il dromos nell'urbanistica dell'Egitto greco-romano. In: Congresso Internazionale ItaloEgiziano. Alessandria e il mondo ellenisticoromano: Alessandria, 23-27 novembre, 1992. Roma, L'Erma di Bretscheneider:205-217.

ROWLANDSON, J. (Ed.)

1998 Women \& Society in Greek \& Roman Egypt. A sourcebook. Cambridge: Cambridge University Press.

SAUNERON, S.

1992 Cosmogonies. G. Posener; S. Sauneron; J. Yoyotte - Dictionnaire de la Civilisation Égytienne. Paris, Fernand Hazan: 67-69.

SHAW, I; NICHOLSON, P.

1995 The Dictionary of Ancient Egypt. London: British Museum Press.

TAKÁCS, S.A.

1995 Isis \& Serapis in the Roman World. Leiden: E. J. Brill.

TÖROK, L.

1995 Hellenistic and Roman Terracottas from Egypt. Roma: "L'Erma" di Bretschneider.

VASQUES, M.S

2000 A religião isíaca no Egito greco-romano: as estatuetas de terracota. Dissertação (Mestrado em Arqueologia). São Paulo, Faculdade de Filosofia, Letras e Ciências Humanas, Museu de Arqueologia e Etnologia, Universidade de São Paulo.

WILKINSON, R.H

2003 The Complete Gods and Goddesses of Ancient Egypt. London: Thames and Hudson. 